\title{
WAGE DYNAMICS IN URBAN BRAZIL: EVIDENCE OF REGIONAL SEGMENTATION OR NATIONAL MARKETS?
}

\author{
William D. Savedoff*
}

\section{Resumo}

Apesar do rápido andamento da integração econōmica nas décadas recentes, ainda existe substancial evidência de diferenças regionais de salário. Diversos estudos têm também abordado o impacto da forma do desenvolvimento econōmico do pais sobre várias categorias ocupacionais e de habilidade. Por outro lado, modelos macrocconōmicos geralmente simplificam os processos dos mercados de trabalho assumindo um único e homogênio mercado de trabalho. São os salários no Brasil determinados por aspectos isolados ocupacionais e regionais ou por fatores nacionais? O presente estudo desenvolve um modelo econométrico para a decomposição das variações no salário anual em efcitos nacionais e regionais/ocupacionais. Tal modelo é aplicado para os dados sobre os níveis de emprego de trabalhadores do sexo masculino nas principais áreas urbanas no Brasil a fim de testar se as variaçōes no salário anual são mais semelhantes entre categorias ocupacionais ou locais. Mostra-se que os salários são afetados tanto por condiçōes locais quanto por tendências ocupacionais nacionais. Mostra-se ainda que os padrōes básicos dos diferenciais de salário regionais e ocupacionais têm-se mantido estáveis.

\begin{abstract}
In spite of Brazil's rapid pace of economic integration in recent decades, there remains substantial evidence of regional differences in wages. Numerous studies have also cited the impact of the country's form of economic development on various skill and occupational categories. On the other hand, macroeconomic models generally simplify labor market processes by assuming a single homogeneous national labor market. Are wages in Brazil, then, determined by isolated regional, occupational, or nationwide factors? This study develops an econometric model for decomposing annual wage changes into national, occupational, and regional effects and applies it to data on male employees in Brazil's major urban areas to test whether the annual wage changes are more similar among occupational or local categories. It shows that wages are affected both by local conditions and national occupational trends, and furthermore that the underlying patterns of regional and occupational wage differentials are quite stable.
\end{abstract}

*Banco Interamericano de Desarrollo. This paper was written when the author was visiting IPEA/INPES.

R. de Econometria

Rio de Janeiro

v. $11, \mathrm{n}^{\circ} 2, \mathrm{p} .161-184$

novembro 1991 


\section{Introduction.}

Brazil is an extensive country of sharp economic, social and geographical contrasts. Its labor force of over 50 million people work in a complete range of formal and informal activities, sectors, and climates. They work in electronics assembly plants in the free zone of Manaus in the heart of the tropical amazon; in the orange groves of Rio de Janciro; the soya fields of Mato Grosso; the automobile plants of São Paulo; and the oil refineries of Salvador. They work for multinationals like IBM and Exxon, for parastatals like Petrobrás and Embraer, for domestic giants like Votorantim or Estrela, for local merchants, for small workshops. They produce sophisticated aircraft for export, and roasted peanuts for sale on street corners. They earn a median income of approximately $\$ 150$ per month, but some earn thousands of dollars per day. On average, those in São Paulo earn twice the wage of those in Fortaleza.

This paper seeks to address one aspect of this extensive diversity: do wages in Brazil appear to be more heavily influenced by local or by national factors? In particular, it divides the urban labor force into geographical and occupational categories and tests whether annual wage changes are more similar among occupational or local categories. It will show that wages are affected both by local conditions and national occupational trends, but that the underlying pattern of regional and occupational wage differentials are remarkably stable and account for a large part of the country's widely unequal wage dispersion.

This paper separates the question of whether wages are determined by local or national conditions from an analysis of the process of wage determination itself. That is, the methodology permits an evaluation of the pattern of wage changes without explicitly addressing whether those wage changes are caused by market forces, bargaining outcomes, political changes, institutional processes, etc. The following two sections discuss the relevance of occupational and regional categories for wage determination in Brazil. They are followed by Section 3 which develops and discusses a model for statistically testing the key issue of whether wages are influenced by national or local factors. Section 4 presents the results of this analysis, while Section 5 concludes the paper by summarizing the findings and exploring their implications. 


\section{Regional wage differentials in Brazil.}

The main question in this paper addresses whether or not wages are affected by national or local conditions. The regional contrast in wages in Brazil has elicited numerous studies, ${ }^{1}$ not to mention a variety of large government programs (e.g. SUDENE, FINOR, etc.). It is evident that Brazil's poor population is disproportionately concentrated in the Northeast, and that wages are generally lower in that region than elsewhere. Some $30 \%$ of Brazil's population resided in the Northeast in 1985 , but $52 \%$ of the families with less than one minimum wage lived in that region. In the metropolitan regions, about $27 \%$ of São Paulo's residents were living below the poverty level in 1985, a low proportion compared to the poverty shares of Fortaleza $(37 \%)$ and Recife (48\%). ${ }^{2}$ The median wage in São Paulo is almost twice as high as in Fortaleza (See Table 1).

Although Brazil is a large country and distances are great, the country has become increasingly integrated in the last several decades. In terms of commerce, interstate trade tripled from 1943 to 1961 , and then increased about ten-fold in the next 20 years. As a share of GDP, this interstate commerce grew from $16 \%$ in 1947 to $33,5 \%$ in 1976 (Ablas \& Fava 1985).

Population movements across regions are also large. The 1980 Census showed that some 40 million people, about $35 \%$ of the population, were living outside their native state. On average, some 1,5 million people move annually from one state to another Savedoff (1990). Furthermore, migration has become significantly easier and less costly. Meneghetti (1988) measured the increasing mobility of people by using census data to show that a $10 \%$ increase in distance reduced migration by some $18 \%$ in 1960 , but only by $6 \%$ in 1980. The increasing integration of interregional trade and population movements indicates that local influences upon wages may be declining in importance relative to national ones.

${ }^{1}$ Many economists have addressed this question, including Bacr (1964), Furtado (1973), Fishlow (1972), Almeida (1989) and Savedoff (1989). Other social scientists have also considered these regional wage differences, including Chaloult (1979) and Mitchell (1981).

2 All figures calculated by the author from the IBGE's tabulations of PNAD 1985, except for the metropolitan region poverty shares which are found in Rocha and Villela (1989). 


\section{Table 1.}

Comparison of hourly wages by metropolitan region median and coefficient of variation for male employees and self-employed - 1985

\begin{tabular}{lcccc}
\hline $\begin{array}{l}\text { Metropolitan } \\
\text { Region }\end{array}$ & $\begin{array}{l}\text { Median Hourly } \\
\text { (Cr\$/hour) }\end{array}$ & $\begin{array}{l}\text { Wage } \\
\text { (US\$/hour) }\end{array}$ & $\begin{array}{l}\text { Expanded } \\
\text { (US\$/year) }\end{array}$ & $\begin{array}{l}\text { Coefficient } \\
\text { of Variation }\end{array}$ \\
Belém & 4,000 & 0.51 & 980.84 & 169 \\
Fortaleza & 2,872 & 0.37 & 704.25 & 173 \\
Recife & 3,181 & 0.41 & 780.02 & 171 \\
Salvador & 4,167 & 0.53 & 1021.79 & 158 \\
Belo Horizonte & 3,958 & 0.51 & 970.54 & 166 \\
Rio de Janeiro & 4,166 & 0.53 & 1021.55 & 156 \\
São Paulo & 5,556 & 0.71 & 1362.39 & 139 \\
Curitiba & 4,688 & 0.60 & 1149.55 & 159 \\
Porto Alegre & 5,000 & 0.64 & 1226.05 & 163 \\
All & 4,167 & 0.53 & 1021.79 & 152 \\
\hline
\end{tabular}

Note: Conversion at official exchange rate October 1,1985 of $\mathrm{Cr} \$ 7,830 / \mathrm{US} \$$ as reported in Conjuntura Econômica, Jan. 1986. Expanded figure represents hypothetical annual income for an individual working 48 weeks for 40 hours/week at the median wage.

Source: Author's tabulations from the IBGE's PNAD data, 1985.

On the other hand, the spatial dispersion and character of employment has not changed in many ways. São Paulo became Brazil's leading center of industrial activity in the 1930s, and the state of São Paulo has maintained its share of over $50 \%$ of national industrial production since 1960. Although employment growth in other regions accelerated in the 1970s and 1980s relative to São Paulo, the base of employment is so large in São Paulo that it continues to generate larger numbers of jobs in absolute terms. In terms of sectoral distribution, then, one might expect local impacts on wages due to sectoral variation in demand and changes in sectoral terms of trade.

In spite of the growing integration of commerce and large population flows, regional wage differences are significant and appear to be relatively stable. ${ }^{3}$ Table 2 shows the real mean log wage for male

${ }^{3}$ Savedoff (1989) argues that this stability is even more longstanding using industrial census data from 1949 to 1980 . 
non-agricultural employees residing in Brazil's nine major metropolitan regions. Even in 1984 and 1985 when the regional wage dispersion is lowest, wages range from $17 \%$ above the mean in São Paulo to $36 \%$ below the mean in Fortaleza. São Paulo is the city with the highest wage level in all years, while Fortaleza and Recife consistently have the lowest wage levels.

For the purposes of this paper, it is interesting to note that the change in wages from year to year is quite comparable across regions. Figure 1 shows how the wage level in some selected cities rise and fall together. Even so, there is significant regional variation. For example, the wage level in Rio de Janeiro seems to have done relatively better than other cities in the late 1970s and to have suffered worse with the recession of the early 1980 s.

Table 3 shows the results of projecting the regional mean log wage for different cities on the mean log wage in São Paulo. These figures are presented not as definitive measures, but rather as suggestive of the wage elasticities between one region and another. As the table shows, the estimated elasticities are all significantly different from zero, and most are significantly less than one. Wages in Belo Horizonte and Rio de Janeiro appear to have moved in concert with São Paulo's wage changes over this period, while the elasticities for the wage levels in the Northeast and Belém show then to be less clearly associated. This evidence is consistent with the notion of an integrated labor market, with some transaction or transportation costs which increase with distance. Nevertheless, this evidence does not, by itself, resolve the question of whether wages are determined by national or local factors.

Do the annual wage changes in Table 2 refiect gains or losses for all individuals in a particular city or only gains for some? Could the relative changes refiect changing compositions of employment or do they actually refiect changes in regional wage levels? Before responding to these questions, occupational wage differentials will be considered as a relevant category for analyzing national wage changes.

\section{Occupational wage differentials in Brazil.}

Occupational wage differentials are evident in Brazil, and have been variously interpreted as the outcome of market forces and skill differentiation (Langoni 1973), as results of social status unrelated 
Table 2.

Mean log wage by year and region

\begin{tabular}{llllllllllllll}
\hline $\begin{array}{l}\text { Metropolitan } \\
\text { Region }\end{array}$ & 1976 & 1977 & 1978 & 1979 & 1981 & 1982 & 1983 & 1984 & 1985 & 1986 & $\begin{array}{c}\text { std. } \\
\text { Dev. }\end{array}$ \\
Belém & 1.94 & 1.98 & 2.02 & 1.87 & 1.93 & 1.94 & 1.55 & 1.46 & 1.55 & 1.90 & 0.20 \\
Fortaleza & 1.82 & 1.96 & 1.88 & 1.71 & 1.79 & 1.82 & 1.32 & 1.23 & 1.25 & 1.76 & 0.26 \\
Recife & 2.03 & 1.92 & 1.93 & 1.80 & 1.87 & 1.89 & 1.48 & 1.30 & 1.40 & 1.77 & 0.24 \\
Salvador & 2.40 & 2.20 & 2.26 & 2.12 & 2.20 & 2.18 & 1.81 & 1.59 & 1.65 & 1.98 & 0.26 \\
Belo Horizonte & 2.35 & 2.07 & 2.38 & 2.24 & 2.13 & 2.12 & 1.69 & 1.47 & 1.56 & 2.03 & 0.31 \\
Rio de Janeiro & 2.36 & 2.42 & 2.43 & 2.30 & 2.23 & 2.20 & 1.76 & 1.54 & 1.59 & 2.04 & 0.32 \\
São Paulo & 2.61 & 2.59 & 2.59 & 2.49 & 2.37 & 2.38 & 1.93 & 1.74 & 1.79 & 2.33 & 0.32 \\
Curitiba & 2.46 & 2.35 & 2.42 & 2.18 & 2.14 & 2.19 & 1.78 & 1.62 & 1.67 & 2.15 & 0.29 \\
Porto Alegre & 2.46 & 2.45 & 2.43 & 2.23 & 2.22 & 2.29 & 1.83 & 1.67 & 1.74 & 2.17 & 0.28 \\
All & 2.40 & 2.36 & 2.34 & 2.27 & 2.15 & 2.16 & 1.73 & 1.55 & 1.61 & 2.06 & \\
Std. Deviation & 0.25 & 0.23 & 0.24 & 0.24 & 0.18 & 0.18 & 0.18 & 0.16 & 0.16 & 0.18 & \\
\hline
\end{tabular}

Note: All wages measured in 1976 cruzeiros.

Source: Author's tabulations from the IBGE's PNAD data.

to productivity (Medeiros 1982), and as a function of institutional positions in relation to the distribution of rents and profits (Sabóia 1989, Lanzana 1987, Menezes 1988). Occupational categories are very difficult to interpret as they are jointly determined by individuals' abilities, training, experience, composition of economic activities, and patterns of organizing work. Nevertheless, there are reasons to expect that wages for particular occupational categories may be relatively homogeneous, and/or that they change together over time.

First, people who exercise similar occupations generally undertake comparable training or apprenticeships which allow them to perform special tasks. Such training and experience is not homogeneous, but for occupational groups it is relatively homogeneous. For example, there are many different ways and places to train for mechanics, farmhands, and bankers, but the range of methods is narrow within any one these occupational groups relative to the methods used by the others. In a market system, each occupation would be treated as a separate market to the degree that there is low elasticity of substitution between groups. This means that each occupation can 




Figure 1.

Mean of log real wages for selected metropolitan regions

have a separate wage refiecting the marginal productivity of workers with those skills as well as the rents they obtain whenever unforeseen changes in demand meet a less than infinitely elastic supply.

Secondly, occupational categories are closely related to the institutional organization of modern firms. Managers obtain higher wages along with perquisites and status when compared to clerical and production workers. To the degree that wages are determined by political economic forces which affect the functional distribution of social income, occupational categories more closely tied to the capitalist class would enjoy wage gains in times when the profit share of social income increases at the expense of other occupational categories (Sabóia 1989, Lanzana 1987). 
Table 3.

Elasticities of mean log wages across metropolitan regions with respect to São Paulo

\begin{tabular}{lcccc}
\hline $\begin{array}{l}\text { Metropolitan } \\
\text { Region }\end{array}$ & Elasticity & $\begin{array}{l}\text { Standard } \\
\text { Error }\end{array}$ & $\begin{array}{c}\text { t-statistic } \\
\text { for } H: \beta=1\end{array}$ & $\begin{array}{c}\text { Statistical } \\
\text { Significance }\end{array}$ \\
Belém & 0.60 & 0.06 & 6.67 & $1 \%$ level \\
Fortaleza & 0.79 & 0.07 & 3.00 & $2 \%$ level \\
Recife & 0.73 & 0.06 & 4.50 & $1 \%$ level \\
Salvador & 0.77 & 0.08 & 2.88 & $5 \%$ level \\
Belo Horizonte & 0.93 & 0.09 & 0.78 & - \\
Rio de Janeiro & 1.00 & 0.05 & 0.00 & - \\
São Paulo & - & - & - & - \\
Curitiba & 0.89 & 0.05 & 2.20 & $10 \%$ level \\
Porto Alegre & 0.87 & 0.04 & 3.25 & $2 \%$ level \\
\hline
\end{tabular}

Note: Elasticities estimated from a simple projection of mean log real wage in the given region upon the mean log real wage in São Paulo as follows:

$$
w_{j}=\alpha+w_{1} \beta+\epsilon_{j}
$$

Each regression contained 10 observations, one for each year, hence there are eight degrees of freedom.

On the other hand, if wages are actually determined by processes which cut across occupational categories, such as internal labor markets, capital intensity of production, sector-specific bargaining factors, etc. ${ }^{4}$ then the occupational categories may mask the "true" wage-determining factors. In such a case, the use of sectoral categories would be more appropriate. Under this alternative model, however, the relative homogeneity of occupational categories in terms of wages will still hold for patterns of annual wage changes so long as the sectoral composition of each group remains stable. Occupational categories, then, are useful for analyzing wage trends whenever national shifts in profit/wage shares, bargaining power, relative scarcity of skills, or differentiated labor demand occur.

\footnotetext{
${ }^{4}$ See for example the work by Dickens and Lang (1987), Krueger and Summers (1987). On Brazil, the importance of sectoralcategories is raised by many authors, including Almeida, et al (1989), Medeiros (1982), and Savedoff (1990).
} 
Table 4 shows that occupational wage differentials are quite large in Brazil's major urban areas. Administrators earn some $100 \%$ more than clerical workers and about $170 \%$ more than service workers. These occupational wage differences are relatively stable over time and move together from year to year. Table 4 shows the real mean log wage for 10 occupational categories over time. The dispersion across occupational groups is high relative to the dispersion across regions, and is highly stable over the entire period. Even so, there are interesting annual variations which could reflect national changes in demand for occupational categories (Lanzana 1987), modifications in federal wage policy (Sabóia 1989), or shifts between capital and labor (Storper 1984). Sales personnel show greater wage variation, being some $30 \%$ below the mean in 1976 , only $18 \%$ below the mean in 1979 , and again $30 \%$ below the mean in 1985 . Service personnel had significant gains from 1979 to 1983 relative to the mean, but suffered a decline again thereafter. Figure 2 shows the wage changes over time for selected occupations. The ranking never changes, but different years reveal somewhat wider or more compressed occupational wage patterns.

As before, it is interesting to project occupational wages upon one group in the sample. Table 5 shows the elasticities of the mean log wage for particular occupational groups when projected upon the mean log wage of administrators. In this case, too, the relationship between wages is significantly different from zero and is positive. In three cases-clerical, skilled production, and transportation and communications workers-the elasticity of wages with respect to administrators' wages is not significantly different from one. In the other cases, professional, technical, sales, semi-skilled production and service personnel, the elasticity appears to be greater than one.

This preliminary evidence suggests that there are strong national factors which affect all the occupational groups, as shown by the sharp drop in wages resulting from the national recession in the early 1980s. Changes in aggregate demand are not the only determinant of occupational wage levels, however, as shown by the distribution of the elasticities: the wages for some groups do not rise and fall in exact proportion with the others. The relative scarcity by education does not seem to be influencing the wage shifts since the wages of administrators and clerical workers seem to move together closely 


\section{Table 4.}

Mean log wage by year and occupation

\begin{tabular}{lllllllllllll}
\hline Occupation & 1976 & 1977 & 1978 & 1979 & 1981 & 1982 & 1983 & 1984 & 1985 & 1986 & $\begin{array}{c}\text { std. } \\
\text { Dev. }\end{array}$ \\
Miscellaneous & 2.32 & 2.23 & 2.23 & 2.15 & 2.12 & 2.11 & 1.69 & 1.54 & 1.58 & 1.98 & 0.27 \\
Administrators & 3.52 & 3.43 & 3.48 & 3.40 & 3.27 & 3.29 & 2.91 & 2.76 & 2.84 & 3.24 & 0.26 \\
Professional & 4.10 & 4.03 & 3.96 & 3.87 & 3.71 & 3.73 & 3.32 & 3.16 & 3.26 & 3.64 & 0.31 \\
Technical & 2.87 & 2.82 & 2.74 & 2.59 & 2.47 & 2.55 & 2.09 & 1.94 & 2.06 & 2.47 & 0.31 \\
Clerical & 2.48 & 2.50 & 2.49 & 2.38 & 2.35 & 2.41 & 1.98 & 1.83 & 1.91 & 2.28 & 0.24 \\
Semi-Skilled & 1.95 & 1.95 & 1.93 & 1.86 & 1.75 & 1.75 & 1.31 & 1.11 & 1.18 & 1.67 & 0.31 \\
Skilled & 2.35 & 2.33 & 2.32 & 2.27 & 2.19 & 2.21 & 1.76 & 1.58 & 1.63 & 2.09 & 0.28 \\
Transport & 2.25 & 2.34 & 2.35 & 2.30 & 2.16 & 2.17 & 1.74 & 1.59 & 1.69 & 2.10 & 0.27 \\
Sales & 2.11 & 2.12 & 2.13 & 2.09 & 1.86 & 1.84 & 1.43 & 1.26 & 1.30 & 1.81 & 0.33 \\
Services & 1.74 & 1.75 & 1.72 & 1.65 & 1.56 & 1.59 & 1.16 & 0.96 & 1.00 & 1.45 & 0.29 \\
All & 2.40 & 2.36 & 2.34 & 2.27 & 2.15 & 2.16 & 1.73 & 1.55 & 1.61 & 2.06 & \\
Std. Deviation & 0.69 & 0.67 & 0.66 & 0.65 & 0.64 & 0.64 & 0.65 & 0.67 & 0.68 & 0.65 & \\
\hline
\end{tabular}

Note: Wages in 1976 Cruzeiros.

Source: Author's tabulations from the IBGE's PNAD data.

over this period. Instead, the pattern of occupational wage changes is more consistent with theories of internal labor markets or other institutional descriptions of formal business organizations in which the wages of some groups are relatively insulated from outside market forces (e.g. administrators, clerical workers, and skilled workers in large formal sector firms) while others are more strongly affected by "external" market forces (e.g. service personnel). Of course, this evidence is only suggestive and, additionally, any factor which affected the composition of these occupational groupings over the time period (such as firing less productive workers during the recession, increasing informality of work arrangements, etc.) would also alter the results.

Does wage variation by occupation reflect shifting relative advantages for each group or does it result from the regional dispersion of occupations which are thereby affected variously by local conditions? The next section develops a methodology for separating and analyzing diverse regional and occupational impacts on wages. 


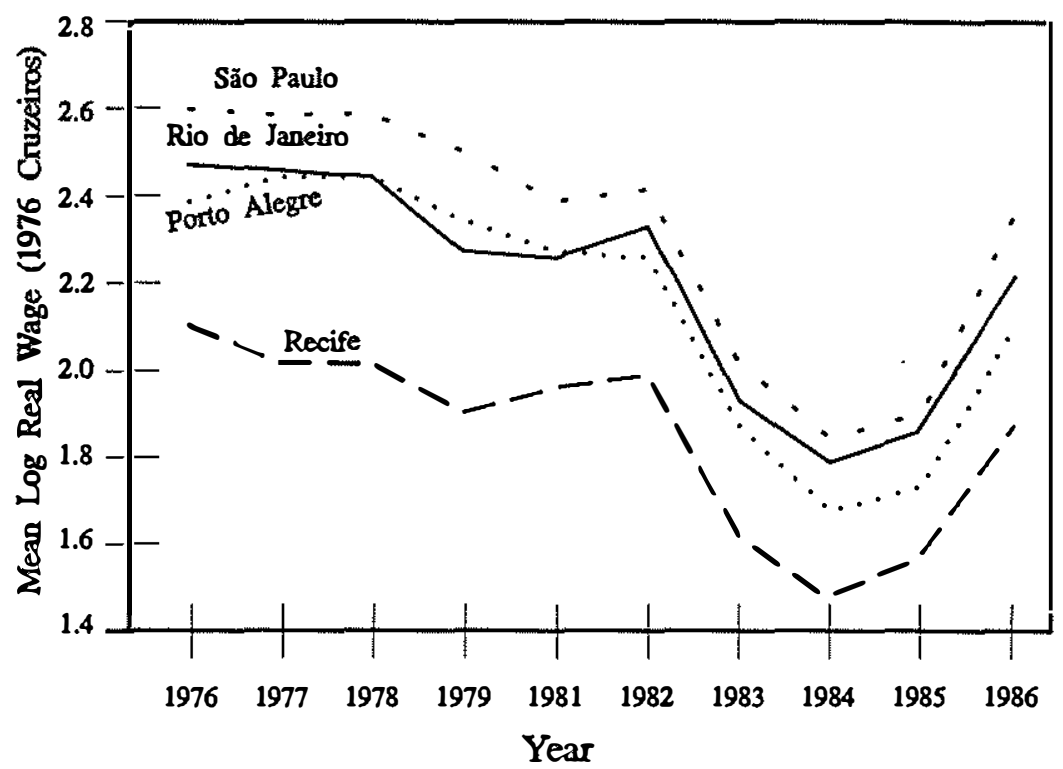

Figure 2.

Mean of log real wages for selected occupations

4. Methodology for exploring regional and occupational wage changes.

With panel survey data, it is possible to follow individuals over time and analyze whether their annual wage changes move more in association with wage changes for other individuals in their own region (regardless of occupation) or for other individuals in the same occupation (regardless of region). Using the PNAD data of the IBGE it is possible to construct a synthetic panel data set by calculating average wages by region and occupation for each year. The use of average wages is useful for eliminating stochastic variation under certain assumptions about random elements of wage determination. This section specifies these assumptions through a formal statistical 


\section{Table 5.}

Elasticities of mean log wages across occupations with respect to administrators

\begin{tabular}{lcccc}
\hline Occupation & Elasticity & $\begin{array}{l}\text { Standard } \\
\text { Error }\end{array}$ & $\begin{array}{c}\text { t-statistic } \\
\text { for } H: \beta=1\end{array}$ & $\begin{array}{c}\text { Statistical } \\
\text { Significance }\end{array}$ \\
Administrator & - & - & - & - \\
Professional & 1.19 & 0.07 & 2.71 & $5 \%$ level \\
Technical & 1.17 & 0.07 & 2.42 & $5 \%$ level \\
Clerical & 0.91 & 0.05 & -1.80 & - \\
Semi-Skilled & 1.18 & 0.04 & 4.50 & $1 \%$ level \\
Skilled & 1.08 & 0.05 & 1.60 & - \\
Transport & 1.02 & 0.06 & 0.33 & - \\
Sales & 1.24 & 0.05 & 4.80 & $1 \%$ level \\
Services & 1.10 & 0.05 & 2.00 & $10 \%$ level \\
\hline
\end{tabular}

Note: Elasticities estimated from a simple projection of mean log real wage in the given region upon the mean log real wage for Administrators as follows: $w_{k}=\alpha+w_{m} \beta+\epsilon_{k}$

Each regression contained 10 observations, one for each year, hence there are eight degress of freedom.

model.

First, let log wages be a function of a variety of individual characteristics.

$$
\ln w_{i}=X_{i} \beta+\epsilon_{i}
$$

where $w_{i}$ is individual $i$ 's hourly wage, $X$ is a vector of all (observed and unobserved) characteristics associated with individual $i$ which determine wages, and $\epsilon_{i}$ is an orthogonal term. The orthogonal term, $\epsilon_{i}$, can be considered to have three components:

$$
\epsilon_{i}=\mu_{i}+\nu_{j}+\varphi_{k}
$$

where

$\mu_{i}=$ random variations in wages associated with individual $i$;

$\nu_{j}=$ disturbances or premia associated with the individual's occupation, $j$; and

$\varphi_{k}=$ disturbances or premia associated with the individual's place of residence, $k$. 
Each of these variables and terms also has a time component, so equation (1) can be rewritten as: ${ }^{5}$

$$
\ln w_{i t}=X_{i t} \beta+\mu_{i t}+\nu_{j t}+\varphi_{k t}+\eta_{t}
$$

where the subscript $t$ represents a particular year and $\eta_{t}$ has been included as a disturbance term specific to a given year, $t$.

If we take the average of all wages across individuals in a given occupation, region, and year, the resulting mean log wage can be written as:

$$
\omega_{\cdot j k t}=X_{\cdot j k t} \beta+\mu_{\cdot t}+\nu_{j t}+\varphi_{k t}+\eta_{t}
$$

where $\omega \cdot j k t=E\left(\ln w_{i j k t} \mid j, k, t\right)$. Now, if the randomness associated with individuals in a given year, $\mu_{i t}$, is independently distributed ${ }^{6}$ with mean zero and is also independent of region and occupation, then the mean log wage for each occupational-regional group in a particular year will be:

$$
\omega \cdot j k t=\bar{X}_{\cdot j k t} \cdot \beta+\nu_{j t}+\varphi_{k t}+\eta_{t}+\xi_{j k t}
$$

where $\xi_{j k t}$ is a stochastic term representing random effects on group wages which result from sampling individuals and which are independent of occupational, regional, or time effects. The key assumption is that of mean independence between individual wage variation $\left(\mu_{i}\right)$ and the included variables, i.e. $E\left(\mu_{i t} \mid j, k, t\right)$. If this independence does not hold, then the classical assumptions on $\xi_{j k t}$ will be violated and lead to inconsistent estimators.

Equation (5) essentially creats a "synthetic individual" with the mean characteristics of the group $(j, k, t)$, written as $\bar{X}_{\cdot j k t}$. This synthetic individual can be followed through time as through part of a panel survey to the degree that the composition of individuals in each

\footnotetext{
${ }^{5}$ In the entire discussion, the impact of personal wage-determining characteristics $(\beta)$ will be assumed constant over time. For a discussion of evidence suggesting that these coefficients in fact change over time, (see Ramos 1990). Further research may be able to decompose the national and local effects on these "returns" to personal characteristics, but will not be addressed here for simplicity.

${ }^{6}$ The independence of the individual errors requires that there is no systematic deviation for clusters of individuals, as would occur with excluded factors such as inter-industry differentials. It is assumed that such effects are small, but future research would have to resolve this empirically.
} 
group remains the same. The process of averaging seeks to eliminate individual variation in earnings $\left(\mu_{i}\right)$ as a source of significant variation in the dependent variable.

In order to facilitate further decomposition of the effects, each term is divided into two parts: one part is the average effect over the entire study period, and the second part is the deviation from this average. In particular, each of the right hand side terms can be defined as:

$$
\begin{aligned}
\bar{X}_{\cdot j k t} & \equiv \bar{X}_{\cdot j k}+\hat{X}_{\cdot j k t} \\
\nu_{j t} & \equiv \bar{\nu}_{j .}+\hat{\nu}_{j t} \\
\varphi_{k t} & \equiv \bar{\varphi}_{\cdot t}+\hat{\varphi}_{k t}
\end{aligned}
$$

where each definition decomposes the time-dependent variable into an average for the entire study period and the deviation in a particular year $t$ from that mean. Note that a similar decomposition for the final term, $\eta$, would be meaningless, since it measures the time-specific deviation from the study period average (measured by a constant term incorporated in $X$ ).

The resulting equation is:

$$
\omega_{\cdot j k t}=\left(\bar{X}_{\cdot j k \cdot}+\hat{X}_{\cdot j k t}\right) \cdot \beta+\left(\bar{\nu}_{j}+\hat{\nu}_{j t}\right)+\left(\bar{\varphi}_{k}+\hat{\varphi}_{k t}\right)+\eta_{t}+\xi_{j k t}
$$

This equation is entirely identified once we know occupation, region, and time period for each synthetic observation along with its mean characteristics. Difficulties arise in specifying what set of variables make up the wage determining characteristics in the vector $X$. This can be addressed with commonly utilized observable variables such as years of schooling, age, and marital status. On the other hand, there are numerous unobservable factors-ability, contacts, quality of school, etc. - which would necessarily be left out. Instead, this paper seeks to capture this set of factors indirectly through the addition of one assumption and a particular mapping. First, it is assumed that the underlying wage-determining characteristics, $X$, do not vary significantly from year to year, i.e.

$$
\hat{X}_{\cdot j k t}=0, \quad \forall j, k, t .
$$

Secondly, since we are not interested in estimating $\beta$-the coefficients on the wage defining characteristics-we can use a matrix of 
dummy variables, $Q$, which represents the interaction of region and occupation, to serve as a proxy for the mean wage defining characteristics of any particular occupation-region group. If there are $J$ regions, $K$ occupations, and $T$ time periods, then $n=J \cdot K \cdot T$ is the number of grouped observations and $Q$ can be defined as a matrix of 1 's and 0 's with $J \cdot K$ columns and $n$ rows. Each column has a single " 1 " in it, indicating the occupation-region category which is associated with that particular observation. The mean characteristics for any particular occupation-region group can be projected upon $Q$ by a matrix $H$ which has $J \cdot K$ rows and $h$ columns, where $h$ is the number of variables in the vector $X$. In matrix notation, then

$$
\bar{X} \equiv Q \cdot H
$$

where $X$ is the matrix of mean wage characteristics for each of $J \cdot K$ occupation-region groups and $H$ is constructed by stacking the $\bar{X}_{\cdot j k}$. vectors. Equivalently, for any particular occupation-region group

$$
\bar{X}_{\cdot j k} \equiv q \cdot H
$$

where $q$ represents the appropriate row vector from $Q$.

With the additional assumption regarding the temporal stability of mean wage-determining characteristics and the one-to-one mapping $H$, equation (9) can be rewritten solely as a function of dummy variables representing occupation, region, year, and their interactions. That is,

$$
\omega_{\cdot j k t}=(q \cdot H) \cdot \beta+\left(\bar{\nu}_{j}+\hat{\nu}_{j t}\right)+\left(\bar{\varphi}_{k \cdot}+\hat{\varphi}_{k t}\right)+\eta_{t}+\xi_{j k t}
$$

can be rewritten in matrix notation as:

$$
w=Q \cdot \lambda+(O \cdot \alpha+O Y \cdot \delta)+(R \cdot \rho+R Y \cdot \gamma)+Y \cdot \tau+\xi
$$

where $w$ is a column-vector of observed mean log wages; while $Q, O, O Y, R, R Y$, and $Y$ are matrices of dummy variables which represent the interaction of occupation and region (with dimension $n x J K$ ), occupation $(n x K)$, the interaction of occupation and time $(n x K T)$, region $(n x J)$, the interaction of region and time $(n x J T)$, and time $(n x T)$, respectively. The coefficients $\lambda, \alpha, \delta, \rho$, and $\gamma$ represent the 
disturbance or premium associated with a respective factor (while $\lambda=H \cdot \beta) . \xi$ is a residual in the sense that it represents all of the variation in the mean log wage which cannot be attributed to all of the groups in a particular year, region, or occupation or to all of the groups in a given occupation in a particular year, a given region in a particular year, or a given region and occupation for all years. The source of this error is unidentified because it could result from the random distribution of $\mu_{i t}$, from excluded factors (such as inter-industry effects), or if the assumption in equation (10) is violated.

Because all of the independent variables are dummy variables, the estimation is essentially non-parametric. For example, $\alpha$ measures the average wage advantage of a particular occupation, $j$, relative to an omitted occupational category. Similarly, $\gamma$ measures the wage advantage (or disadvantage) for all of the group in region $k$ in a particular year $t$ relative to the omitted year and region. In the event that there is a stable impact upon wages for particular occupations and regions, the coefficients $\alpha$ and $\rho$ will be statistically significant and non-zero. If on the other hand, occupations and regions have no generalized impact upon wages, these coefficients will be indistinguishable from zero. Additionally, if there is no annual fluctuation in occupational and regional effects, then the coefficients $\delta$ and $\gamma$ will be statistically indistinguishable from zero. If on the other hand there is significant annual fluctuation in occupational and regional effects, then the coefficients $\delta$ and $\gamma$ will be statistically significant and non-zero.

A particular case that will be investigated is the hypothesis that occupational and regional effects are non-zero and that they represent an underlying stable pattern of effects, only modified from year to year by fluctuations which have no net impact toward divergence or convergence. This particular set of hypotheses can be represented by

$$
\begin{aligned}
& H_{0}: \alpha_{j} \neq 0, \forall j \\
& H_{1}: \Sigma \delta_{j}=0, \forall j
\end{aligned}
$$

for occupational categories; and

$$
\begin{aligned}
& H_{3}: \rho_{k} \neq 0, \forall k \\
& H_{4}: \Sigma \gamma_{k}=0, \forall k
\end{aligned}
$$

for the regional categories. 


\section{Sample and results.}

The model and hypothesis tests described in Section 3 were applied to a sample derived from the IBGE's annual household survey data (PNAD). The sample included all male employees over 14 years of age residing in Brazil's nine major metropolitan regions who receive positive remuneration in any activity except agriculture or public administration. The sample excluded rural workers because of the difficulties in comparing urban and rural wages, but did not distinguish between formal and informal sector employees, whether by work card status or contribution to social security. The sample excluded women because women's earnings have a higher degree of dispersion than men's earnings and because the regional composition of each occupation-region group could be strongly affected by the large changes in female labor force participation rates which have occured during this period (Sedlacek 1990). The use of the 9 metropolitan regions enforced some homogeneity upon the place of residence, since other urban areas are much more dispersed and varied. Self-employed and public sector employees were also excluded because of evidence that wage determination is significantly different for these subgroups (Savedoff 1990). The resulting sample included approximately 30,000 individuals from each annual survey.

The log wage was calculated for each individual in the sample, and averages across these individuals were calculated for each occupation-region cell in each year. The wages were also deflated by the Índice Geral de Preços to eliminate nominal price effects. The individuals were grouped into 10 occupations and 9 metropolitan regions over an 11 year period from 1976 to 1986 . The year of the Decennial Census (1980) was excluded because the PNAD survey was not conducted that year. Consequently, the sample includes 10 surveys. This resulted in 90 occupation-region groups for each sample, and 900 observations in all for the entire study period. The average number of observations in a particular occupation-region group for any given year was 340 , and only $1.22 \%$ of the groupings included fewer than 30 observations.

The results of the econometric analysis are shown in Table 6 and indicate that there are significant occupation and region-specific effects on wages. The regression captures virtually all of the log wage variation, with an $R^{2}$ of 0.99 . The low unexplained variation 
indicates that $\xi$ is small and therefore that the potential problem of excluded independent effects is small. This does not, however, rule out the possibility that left-out effects may be correlated with included terms, thereby leading to bias.

Table 6 includes the various hypothesis tests discussed above. The joint hypothesis that coefficients for the year variables are zero is easily rejected by an $F$-test at the $0.1 \%$ level, indicating that there are national influences upon annual wage changes independent of occupational and regional categories. This confirms the observations made about Figures 1 and 2 which show the relatively strong impact of the nationwide recession and recovery upon the overall wage level. The metropolitan region variables are jointly significant at the $0.1 \%$ level. Hence, over the entire period there is a statistically significant mean difference between regional wage levels, independent of time and occupational effects. The occupation variables are jointly significant at the $0.1 \%$ level, showing that they too account for a significant part of the wage differences. The coefficients on the interactions are also significantly different from zero in all three cases: occupationregion, occupation-year, and region-year. Following the interpretation discussed in Section 3, the significance of the occupation-year and region-year interaction terms indicates that both national and local factors influence wage changes in Brazil's urban labor markets.

The analysis of covariance suggests that the occupational wage structure is somewhat more important to explaining annual variations in wages since it has the greatest marginal contribution to the explained sum of squares, some $3.6 \%$. It is followed by the interaction of occupation and region (1.3\%) and the main effect for the year $(1.0 \%)$. The marginal contributions for region $(0.1 \%)$, regionyear $(0.5 \%)$, and occupation-year $(0.3 \%)$ are all smaller. It should be noted, however, that interpreting these marginal contributions as measures of the relative importance of each set of variables in wage determination is problematic. ${ }^{7}$ Nevertheless, these marginal effects show that we cannot reject the hypothesis that regional-specific and occupational-specific effects are important in wage determination.

Some comments are in order about the interpretation of the final results. First, if the assumption that the average individual's wage-

7 The use of proportions of explained sums of squares to indicate relative importance of included variables is criticized by Hendry and Marshall (1983). 
Table 6.

Results of statistical tests for complete regression

\begin{tabular}{|c|c|c|c|c|}
\hline Source & $\mathrm{DF}$ & $\begin{array}{l}\text { Sum of } \\
\text { Squares }\end{array}$ & $\begin{array}{l}\text { Mean } \\
\text { Square }\end{array}$ & F-Value \\
\hline Model & 251 & 131314 & 523 & 481 \\
\hline Error & 648 & 705 & 1.09 & \\
\hline C Total & 899 & 132019 & & \\
\hline Root MSE & .1 .04 & R-Square & 0.99 & \\
\hline Dep Mean & 2.05 & \multirow[t]{2}{*}{ Adj R-Sq } & 0.99 & \\
\hline C.V. & 50.81 & & & \\
\hline \multicolumn{5}{|c|}{$\begin{array}{l}\text { Joint Hypothesis Tests } \\
\text { (all significant at the } 0.1 \% \text { level) }\end{array}$} \\
\hline Tests & Category & F-Value & $\begin{array}{l}\text { Degrees of } \\
\text { Freedom } \\
\text { (Numerator) }\end{array}$ & $\begin{array}{l}\text { Marginal } \\
\text { Contribution } \\
\text { to ESS }\end{array}$ \\
\hline Main & Year & 131.7 & 9 & 1290 \\
\hline Main & Occupation & 492.3 & 9 & 4815 \\
\hline Main & Region & 22.33 & 8 & 194 \\
\hline Interaction & Occupation-Region & 21.5 & 72 & 1684 \\
\hline Interaction & Occupation-Year & 5.04 & 81 & 444 \\
\hline Interaction & Region-Year & 7.68 & 72 & 601 \\
\hline Sums of & Occupation-Year & 7.22 & 9 & \\
\hline Coefficients & Region-Year & 3.58 & 8 & \\
\hline
\end{tabular}

Note: Sums of Coefficients refers to hypotheses 1 and 3 as explained in the text.

determining characteristics are stable through time is incorrect, then this omitted source of annual variation will bias the other coefficients. On the other hand, specifying this term would have introduced the problem of which variables ought to be included. It may not be unreasonable to expect that average attributes affecting wages change little from year to year when one considers such factors as age, education and marital status to be the prime candidates for these variables in a particular occupation-region group. For example, individuals in a particular sample will all age from one year to the next, but the group 
of people in the following year's sample will include new entrants as well as excluding older workers who retire or die. Hence, the average age may easily remain essentially the same. This was in fact confirmed by calculating the average age and schooling of the different occupation-region groups. The changes in these averages over time were relatively small and were not systematically associated with the business cycle or changes in the sampling method. ${ }^{8}$

On the other hand, it is still possible that changes in the attributes of those included in the sample changed from one year to the next. Selection effects may vary systematically over time, such as choices over who to fire in a recession. If less productive workers are laid off in economic downturns, then the composition of the remaining employed category of workers will have systematically more productive attributes. Also, the sectoral composition of the groups may be affected systematically. To the degree that these factors may have significance, the occupation-or region-specific effects would be overestimated.

It is important to note that the coefficients decompose the variation in mean wages without necessarily implying a particular causal model. A good example is the coefficient $t$ which measures the average annual variation across all occupational and regional groups. This term measures the real change in mean wages common to all groups in a particular year, but it does not tell us anything about why the real wage changed in that year. Similarly, a positive coefficient on the dummy variable for a particular occupation in a given year tells us that occupation received a real wage gain without relating this to shifts in supply or demand, bargaining power, government policy, or any other conceivable theory of wage determination. This paper did not seek to distinguish these effects, only to show evidence that the annual wage changes are systematically related to occupational and regional groupings and hence indicate the operation of local and national markets.

${ }^{8}$ The average age for clerical workers in Salvador over the entire period (19761986) was 31.5 years, with a minimum of 30.2 and a maximum of 33.1. The standard deviation of this group's average age was 1.0, representing a coefficient of variation of $3.2 \%$. For all 90 occupation-region categories, the average coefficient of variation was $3.0 \%$. Note that this average measure of dispersion is an overestimate of the true dispersion since the cell averages are themselves distributed with some positive error. 
In terms of the questions raised in Section 3, a further hypothesis was tested: are the occupational and regional effects entirely stable, or is there significant annual deviation from these main effects? Recall that these hypotheses can be presented as

$$
H_{1}: \Sigma \delta_{j t}=0, \forall_{j}
$$

for occupational categories; and

$$
H_{3}: \Sigma \gamma_{k t}=0, \forall_{k}
$$

for regional categories. As shown in Table 6 next to the "Sums of Coefficients" row, these hypotheses were rejected at the $0.1 \%$. In other words, although we have clear evidence of a strong pattern of occupational wage differences and a strong pattern of regional wage differences, we cannot claim that these patterns are so persistent that there is no "drift" over time. This conclusion should be viewed cautiously, however, due to the short time period of analysis and the relative simplicity of the hypothesis test which cannot distinguish between cyclical and secular deviations. Considering the wage trends presented in Figures 1 and 2, this statistical test is probably quite sensitive to the selection of years included in the sample.

\section{Conclusions and implications.}

This paper has shown that in Brazil, both national and local factors affect wages in the country's major metropolitan regions. This would not be a dramatic finding except that Brazil is a country of continental dimensions with large regional differentiation and many non-market labor institutions. It appears that the pace of commercial integration and increasing possibilities of migration have created a significant national integration of wage determining processes. Nevertheless, significant local effects remain in evidence.

The evidence of national effects indicates that regionally-targeted labor policies are likely to have spillover effects. This may be desirable in cases where projects or policies are spatially concentrated but it is hoped that their benefits will be more widely dispersed. It is less helpful for programs aimed at improving wages in a target area without spillover. The importance of regional influences on wages, 
however, also suggests that comparative work may elicit key factors which contribute to improving wage levels and income distribution, and thereby suggest appropriate public policy for the country's grave regional disparities. In all, the evidence shows that wages in Brazil result from dynamics which have strong national and local components and that it would be mistaken to treat wage determination as either a purely national or an isolated regional process.

\section{References}

Ablas, L. A. 1985. Intercâmbio Desigual e Subdesenvolvimento Regional no Brasil. São Paulo: Pioncira/FIPE.

Ablas, L. A. Müller, A. E. \& Smith, R. 1985. Dinâmica Espacial do Desenvolvimento Brasileiro I. São Paulo: IPE-USP.

Ablas, L. A. \& Fava V. L. 1985. Dinâmica Espacial do Desenvolvimento Brasileiro II. São Paulo: IPE-USP.

Almeida dos Reis, A., José Guilherme \& Ricardo Pacs de Barros 1989. "Income inequality and the distribution of education: regional differences in inequality." Yale University Microeconomics Workshop in Labor and Population.

Baer, W. 1964. "Regional inequality and economic growth in Brasil." Economic Development and Cultural Change 12:268-285.

Chaloult, Yves 1979. "Regional differentials and the role of the state: economic-political relationships between the Northeast and Southeast of Brazil." Latin American Studies Program, Dissertation Series, Cornell University no 70 .

Dickens, W. T. \& Katz, L. F. 1987. "Inter-industry wage differences and industry characteristics." In Lang, K. \& Leonard, J. S., eds., Unemployment and the Structure of Labor Markets. New York: Basil Blackwell.

Fishlow, A. 1972. "Brazilian size distribution of income." American Economic Review 62: 391-402.

Hendry, D. F. \& Marshall, R. C. 1983. "On high and low $R^{2}$ contributions." Oxford Bulletin of Economics and Statistics 45:313316.

Kon, A. 1989. "Considerações sobre as diferenças regionais da estrutura ocupacional brasileira." In Anais do XVII Encontro Nacional de Economia III. Fortaleza: ANPEC. 
Krueger, A. B. \& Summers, L. H. 1987. "Reflections on inter-industry wage structure." In Lang, K. \& Leonard, J. S., eds., Unemployment and the Structure of Labor Markets. New York: Basil Blackwell.

Langoni, C. G. 1973. Distribuiçâo de Renda e Desenvolvimento Econômico no Brasil. Rio de Janeiro: Expresssão e Cultura.

Lanzana, A. E. T. 1987. "Diferenças de salários na economia brasileira: uma análise do período 1960-1983." São Paulo: Instituto de Pesquisas Econômicas.

Luque, C. A. \& Chahad, J. P. Z. 1985. "Formação de salários no Brasil: uma contribuição ao debate." Estudos Econômicos 15: 37-46.

Medeiros, J. A. de S. 1982. "Alcance e limitações da teoria do capital humano: diferenças de ganhos no Brasil em 1973." São Paulo: IPE-USP.

Meneghetti Neto, A. 1988. "O efeito da variável distância na migração interna brasileira: algumas considerações." In Anais XVI Encontro Nacional de Economia III. Belo Horizonte: ANPEC.

Menezes, W. F. "Parcela salarial na indústria de transformação do Brasil: 1970-1981." In Anais do XVI Encontro Nacional de Economia III. Belo Horizonte: ANPEC 1988.

Mitchell, S., ed. 1981. The Logic of Poverty: the Case of the Brazilian Northeast. London, Boston, and Henley: Routledge \& Kegan Paul.

Morley, S., Barbosa, M. \& de Souza M. C. C. 1979. "Evidence on the internal labor market during a process of rapid growth." Journal of Development Economics 6:261-286.

Ócio, D. Z. 1986. "Salários e política salarial." Revista de Economia Política 6:5-26.

Ramos, L. 1990. "The distribution of earnings in Brazil: 1976-1985." Ph.D. Dissertation, University of California, Berkeley,.

Rocha, S. \&Villela, R. 1990. "Caracterização da subpopulação pobre metropolitana nos anos 80 - resultados de uma análise multivariada." Revista Econômica Brasileira 44:35-52.

Sabóia, J. 1989. "Salário e produtividade na indústria no longo prazo." In Anais do XVII Encontro Nacional de Economia III. Fortaleza: ANPEC.

Savedoff, W. D. 1990. "Regional wage differences in Brazil's urban 
labor Markets." Ph.D. Dissertation, Boston University. 1989. "Temporal stability of regional wage differentials in Brazil." Texto para Discussão Interna, no 175 , Rio de Janeiro, IPEA/INPES.

Guilherme, S. 1990. "Participação da mulher no mercado de trabalho." Mimeo. Rio de Janeiro, IPEA/INPES.

Smith, R. E. 1986. "Indexação salarial, rotatividade, e variaçōes de salário nominal nas indústrias textil e de borracha no estado de São Paulo - 1966/76." Estudos Econômicos 16:227-241.

Souza, P. R. \& Baltar, P. E. 1983. "The minimum wage and wage rates in Brazil." Brazilian Economic Studies no 7, Rio de Janeiro, IPEA/INPES.

Storper, Michael 1984. "Who benefits from industrial decentralization? Social power in the labor market, income distribution, and spatial policy in Brazil." Regional Studies 18:143-164.

Velloso, R. C. 1990. "Salário mínimo e taxa de salários: o caso brasileiro." Texto para discussão interna, no 192, Rio de Janeiro, IPEA/INPES. 